\title{
A DESCRIPTIVE APPROACH TO MOBBING: THE ROLE OF SELF ESTEEM AND BODY IMAGE AT WORK
}

\author{
Nevin Kılıç ${ }^{1}$, Berra Bekiroğlu², Hüdanur Özdemir ${ }^{2}$, \& Arkun Tatar ${ }^{1}$ \\ ${ }^{1}$ Department of Psychology, FSM Vakaf University / Assistant Professor (Turkey) \\ ${ }^{2}$ Psychologist (Turkey)
}

\begin{abstract}
The present study is aimed to investigate perceived mobbing, self-esteem, and body image together. In this direction, relations between these constructs were examined, and mobbing scores of different socio-demographic groups were compared. Participants of the study were 223 female and 219 male, a total of 442 people, who have been working in public (165 people) or private sector (277 people) more than a year. Data were collected through the A Mobbing Scale, the Two Dimensional Body Image Scale, and the Coopersmith Self-Esteem Inventory. In order to explain perceived mobbing, different regression models and in order to demonstrate the relations between variables, different path models were tested. Results suggest that, self-esteem is the most important predictor of mobbing. Respectively, body image affects perceived mobbing indirectly through self-esteem. According to the results of covariance analysis that was performed for comparing socio-demographic groups, number of working years, and age has no significant effect on mobbing scores. In addition, results reveal that especially poor body image, low self-esteem, and bad economic conditions may be prominent risk factors for exposure to mobbing.
\end{abstract}

Keywords: Mobbing, self-esteem, body image.

\section{Introduction}

Body image, which has become an increasingly popular research topic within various fields such as social and health sciences, is a notion that is often used interchangeably with physical appearance (Cash, 2004; Furnham, Badmin \& Sneade, 2002). Although body image is frequently equated with physical appearance, it refers to a much broader concept than the latter, and it is conceptualized as a multidimensional construct that encompasses individuals' cognitive, emotional and behavioral evaluations of their physical appearances. It is stated that body image consists of two main components, namely, perceptions and attitudes. The perceptual component contains individuals' personal evaluations of their physical appearances whereas the attitudinal component contains individuals' feelings or thoughts about their own bodies (Chase, 2001; Hayes, D'Anci \& Kanarek, 2011; Stokes \& Frederick-Recascino, 2003; Wenninger, Weiss, Wahn \& Staab, 2003).

Although body image is conceptualized as a subjective construct, it is demonstrated that individuals' perceptions of and attitudes towards their bodies are influenced by socio-cultural ideals and expectations that are presented in media through various messages (Cash \& Labarge, 1996; Lee, Lee, Choi, Kim \& Han, 2014; Sainsbury, 2009; Veldhuis, Konijn \& Seidell, 2012). Internalization of these ideal body portrayals has an important impact on individuals' body image (Bessenoff, 2006; Chase, 2001). The perceived difference between ideal norms and the personal evaluations of one's own physical appearance may lead to dissatisfaction with body and cause body image distortion. Negative evaluation or distorted perspective towards body is linked to psychological problems such as depression, anxiety, eating disorders and so on (Friederich et al., 2007; Lee et al., 2014; Swami, Hadji-Michael \& Furnham, 2008; Thompson, Dinnel \& Dill, 2003; Weawer \& Byers, 2006)

In previous studies, body image has been found to be closely related to self-esteem which also encompasses overall perception of self (Latha, Hegde, Bhat, Sharma \& Rai, 2006; Sainsbury, 2009). In this direction, some researchers suggest that body image is an essential component of self-esteem, whereas others hold the view that body image and self-esteem are related but different constructs (Kostanski \& Gullone, 1998; Sainsbury, 2009). Despite the different approaches on the relation between these two constructs, it has commonly been assumed that body image distortion may have negative affects on self-esteem. In other words, it is considered that negative body image is reflective of low 
self-esteem (Latha et al., 2006). On the other hand, it is widely believed that people who look physically attractive are more likely to be successful, happy, intelligent, sociable, and emotionally stable (Chase, 2001). Besides, physically attractive and successful people are judged more favorably, treated better, appreciated greatly by society (Sainsbury, 2009). However, in the job context, individuals' physical appearances comprise risk factors for becoming target of regularly repeated, undesirable, destructive, hostile, and inappropriate behaviors such as ostracizing, insulting, humiliating and so on (De Pedro, Sánchez, Navarro \& Izquierdo, 2008; Einarsen, 1999; Leymann, 1990; Tomi?, 2012; Turaç \& Şahin, 2014; Tutar \& Akbolat, 2012). Whatever the reason, exposure to mobbing may lead to severe stress related outcomes such as psychosomatic symptoms, depression, anxiety, PTSD (Post-Traumatic Stress Disorder), suicidal thoughts and behaviors (Szigety, 2012; Notelaers, Vermunt, Baillien, Einarsen \& De Witte, 2011; Leymann \& Gustafsson, 1996). Low self-esteem is considered both a consequence of mobbing and a vulnerability factor for it (Einarsen, Raknes \& Matthiesen, 1994; Einarsen, 2000; Şenol et al., 2015; Szigety, 2012).

As discussed above, although several divergent accounts on the relation between physical appearance and exposure to mobbing have been proposed, there is a notable paucity of research on body image and mobbing relation in job context. In this direction, the present study is aimed to examine this relation.

\section{Methods}

\subsection{Participants}

Primary exclusion criteria for participation in the study were working at non-revenue generating jobs, working less than a year, and working in a job that there are less than five employees. Participants were 223 female (50.5\%) and 219 male (49.5\%), a total of 442 people, ranging in age between 18 and 64 (Mean $=29.50, \mathrm{SD}=7.79$ years). $165(37.3 \%)$ of the participants have been working in public sector and $277(62.7 \%)$ in private sector. Working years of the participants ranged between 1 and $48($ Mean $=6.32$, $\mathrm{SD}=7.38$ years).

\subsection{Materials}

Data were collected through the A Mobbing Scale, the Two Dimensional Body Image Scale, and the Coopersmith Self-Esteem Inventory.

The A Mobbing Scale, consists of 30 items $(\alpha=0.96)$ rated on a 5-point Likert-type scale (on which $1=$ Very Inaccurate and $5=$ Totally Accurate). High scores indicate higher level of perceived mobbing (Tatar, Namlı et al., 2017).

Two Dimensional Body Image Scale, is a self-report questionnaire, consisting of 63 items scored on a 5-point Likert scale ranging from 1 (Dislike Extremely) to 5 (Like Extremely). Besides the overall score $(\alpha=0.93)$, the scale also provides scores for the two sub-dimensions called Functions $(\alpha=0.83)$ and Appearance $(\alpha=0.92)$. Higher scores indicate satisfaction with body in general, physical appearance, and functions of body parts (Tatar, Saltukoğlu et al., 2017).

Short Form of the Coopersmith Self-Esteem Inventory for Adults, consists of 25 items $(\alpha=0.81)$ scaled dichotomously (Yes $=4$, No $=0$ ) with higher scores indicating higher level of self-esteem (Eriş \& İkiz, 2013).

\subsection{Procedure and data analysis}

Data were collected through an online survey within a 1-month period. Convenient sampling method was used for sharing the web link to the survey with people who met the inclusion criteria and accepted to participate in the study voluntarily. In the first place, internal consistency reliability coefficients for the scales were calculated. Afterwards, for determining the relationships between the variables, Pearson correlation analyses; for predicting the perceived mobbing scores, simple and multiple linear regression analyses; and for examining the direct and indirect effects of the variables on each other, path analyses were performed. Finally, the mean scores of the groups were subjected to the one-way Analysis of Covariance (ANCOVA) in terms of the perceived mobbing scores.

\section{Results and discussion}

In this study, results of the different regression and path analyses were reported together designedly with the aim of demonstrating the differences between the models and the changes in results with the transition from one model to the other. Another advantage of evaluating variables both together and separately is that it provides comparable results that lead to a better understanding of their relation to mobbing. 
Results of the simple and multiple linear regression analyses showed that in predicting the perceived mobbing scores, self-esteem is the most important predictor. The increase in the $\mathrm{R}^{2}$ values (0.055-0.152) obtained in the five different regression models indicates that body image has a significant complementary role in self-esteem while predicting the mobbing scores. Although regression analyses resulted in the expected direction, for investigating the relations between body image, self-esteem, and mobbing further, nine different models were tested through the path analysis in order to demonstrate the differences between models and determine the better fitting model. Besides the direct relationship between body image and mobbing, results of the last model, in which the overall total score of the Two-Dimensional Body Image Scale and its sub-dimensions were correlated with mobbing both directly and through self-esteem, reveals that body image has an impact on mobbing and self-esteem may play a mediating role between body image and perceived mobbing. Although the significantly improved fit indices and compatible results with the findings of regression analyses in general, there was a difference between the two methods that sub-dimensions of the Two Dimensional Body Image Scale did not contribute much in explaining the variance related to mobbing in regression analysis whereas specification of these sub-dimensions improved the model fit significantly in path analysis.

In order to support the results obtained from previous analyses and to explain the difference observed between these two different methods, mobbing scores were compared in terms of body image and self-esteem via covariance analysis. In this direction, perceived mobbing levels of different groups that were formed based on the socio-demographic characteristics of the participants were compared. It has been thought that especially age (in terms of body image) and number of the working years of participants (in terms of interpersonal relationships at workplace) may have a common effect on perceived mobbing scores, therefore these variables were included and controlled as covariates. However, contrary to expectations, findings suggest that these variables did not affect the mobbing scores as covariates. ANCOVA results support the results obtained from both regression and path analyses. While there is no difference found between the body image groups in terms of the mobbing scores, there is a significant difference found between the self-esteem groups. On the other hand, it was hypothesized that that there may be differences in mobbing perceptions of body image groups relying on the previous studies which have suggested that both being physically unattractive and having an extremely attractive physical appearance are risk factors for exposure to mobbing (Tomic, 2012; Turaç \& Şahin, 2014). However, results of the present study do not support the previous findings as there was no difference found in this direction, additionally no interaction was observed between the self-esteem and body image groups. On one hand, this result indicates that there is no interaction between these constructs. On the other hand, this contradictory result may be due to unmeasured variables (such as body image, which could account for some aspects of the results) or other uncontrolled error sources in previous studies. Either way, it is concluded that relations between these constructs need to be reconsidered with more sophisticated and complex designs. When results for the socio-demographic variables are evaluated as a whole, it is understood that "weak" people seem to be more vulnerable to mobbing in general. In this study, it is seen that especially distorted body image, low self-esteem, and bad economic conditions are prominent risk factors for exposure to mobbing.

\section{References}

Bessenoff, G. R. (2006). Can the media affect us? Social comparison, self-discrepancy, and the thin ideal. Psychology of Women Quarterly, 30(3), 239-251.

Cash, T. F. (2004). Body image: past, present, and future. Body Image, 1(1), 1-5.

Cash, T. F., \& Labarge, A. S. (1996). Development of the Appearance Schemas Inventory: a new cognitive body-image assessment. Cognitive Therapy and Research, 20(1), 37-50.

Chase, M. E. (2001). Identity development and body image dissatisfaction in college females. (MD thesis), The Graduate Collage University of Wisconsin, Menomonie, WI.

De Pedro, M. M., Sánchez, M. I. S., Navarro, M. C. S., \& Izquierdo, M. G. (2008). Workplace mobbing and effects on workers' health. The Spanish Journal of Psychology, 11(1), 219-227.

Einarsen, S. (1999). The nature and causes of bullying at work. International Journal of Manpower, 20(1/2), 16-27.

Einarsen, S. (2000). Harassment and bullying at work: a review of the Scandinavian approach. Aggression and Violent Behavior, 5(4), 379-401.

Einarsen, S., Raknes, B. R. I., \& Matthiesen, S. B. (1994). Bullying and harassment at work and their relationships to work environment quality: an exploratory study. European Journal of Work and Organizational Psychology, 4(4), 381-401. 
Eriş, Y., \& İkiz, F. E. (2013). Ergenlerin benlik saygısı ve sosyal kaygı düzeyleri arasındaki ilişki ve kişisel değişkenlerin etkileri. Turkish Studies, 8(6), 179-193.

Friederich, H. C., Uher, R., Brooks, S., Giampietro, V., Brammer, M., Williams, S. C., Herzog, W., Treasure, J., \& Campbell, I. C. (2007). I'm not as slim as that girl: neural bases of body shape self-comparison to media images. Neuroimage, 37(2), 674-681.

Furnham, A., Badmin, N., \& Sneade, I. (2002). Body image dissatisfaction: gender differences in eating attitudes, self-esteem, and reasons for exercise. The Journal of Psychology, 136(6), 581-596.

Hayes, J. F., D’Anci, K. E., \& Kanarek, R. B. (2011). Foods that are perceived as healthy or unhealthy differentially alter young women's state body image. Appetite, 57(2), 384-387.

Kostanski, M., \& Gullone, E. (1998). Adolescent body image dissatisfaction: relationships with self-esteem, anxiety, and depression controlling for body mass. The Journal of Child Psychology and Psychiatry and Allied Disciplines, 39(2), 255-262.

Latha, K. S., Hegde, S., Bhat, S. M., Sharma, P. S. V. N., \& Rai, P. (2006). Body image, self-esteem and depression in female adolescent college students. Journal of Indian Association for Child and Adolescent Mental Health, 2(3), 78-84.

Lee, H. R., Lee, H. E., Choi, J., Kim, J. H., \& Han, H. L. (2014). Social media use, body image, and psychological well-being: a cross-cultural comparison of Korea and the United States. Journal of Health Communication, 19(12), 1343-1358.

Leymann, H. (1990). Mobbing and psychological terror at workplaces. Violence and Victims, 5(2), 119-126.

Leymann, H., \& Gustafsson, A. (1996). Mobbing at work and the development of post-traumatic stress disorders. European Journal of Work and Organizational Psychology, 5(2), 251-275.

Notelaers, G., Vermunt, J. K., Baillien, E., Einarsen, S., \& De Witte, H. (2011). Exploring risk groups workplace bullying with categorical data. Industrial Health, 49(1), 73-88.

Sainsbury, D. C. (2009). Body image and facial burns. Advances in Skin and Wound Care, 22(1), 39-44.

Senol, V., Avsar, E., Akca, P. R., Argun, M., Avsarogullari, L. \& Kelestimur, F. (2015). Assessment of mobbing behaviors exposed by the academic personnel working in a university. Turkey. Journal of Psychiatry, 18(212), 2-10.

Stokes, R., \& Frederick-Recascino, C. (2003). Women's perceived body image: relations with personal happiness. Journal of Women and Aging, 15(1), 17-29.

Swami, V., Hadji-Michael, M., \& Furnham, A. (2008). Personality and individual difference correlates of positive body image. Body Image, 5(3), 322-325.

Szigety, T. (2012). Early predictors of workplace mobbing. Procedia-Social and Behavioral Sciences, 33, 418-422.

Tatar A., Namlı M., Özüdoğru, M.T., Uysal, A.R., Yeșilkanat G., Bahadır, E., Kalender, B., \& Aydın, S. (2017). A Psikolojik Yıldırma Ölçeği'nin geliştirilmesi ve psikometrik özelliklerinin incelenmesi. Journal of Behavior at Work, 2(2), 79-88.

Tatar, A., Saltukoğlu, G., Aksu, F., Haşlak, D. F., Zekioğlu, A., Kılıç, N., \& Bekiroğlu, B. (2017). İki Boyutlu Beden İmgesi Ölçeği'nin genel örnekleme uyarlanması, psikometrik özelliklerinin madde cevap kuramı ile incelenmesi ve cinsiyet farklılıklarının karşılaştırılması. Researcher: Social Science Studies, 5(4), 21-40.

Thompson, T., Dinnel, D. L., \& Dill, N. J. (2003). Development and validation of a body image guilt and shame scale. Personality and Individual Differences, 34(1), 59-75.

Tomic, M. (2012). Mobbing: the incidence of mobbing activities and differences regarding workplace and gender. Megatrend Review, 9(1), 243-252.

Turaç, I. S., \& Şahin, B. (2014). Mobbinge maruz kalma durumunun belirlenmesi: hemşireler üzerine bir çalışma. Eskişehir Osmangazi Üniversitesi Sosyal Bilimler Dergisi, 15(1), 87-112.

Tutar, H., \& Akbolat, M. (2012). Sağlık çalışanlarının yönetici cinsiyetleri bakımından mobbing algıları. Selçuk Üniversitesi Sosyal Bilimler Enstitüsü Dergisi, 28, 19-29.

Veldhuis, J., Konijn, E. A., \& Seidell, J. C. (2012). Weight information labels on media models reduce body dissatisfaction in adolescent girls. Journal of Adolescent Health, 50(6), 600-606.

Weaver, A. D., \& Byers, E. S. (2006). The relationships among body image, body mass index, exercise, and sexual functioning in heterosexual women. Psychology of Women Quarterly, 30(4), 333-339.

Wenninger, K., Weiss, C., Wahn, U., \& Staab, D. (2003). Body image in cystic fibrosis-development of a brief diagnostic scale. Journal of Behavioral Medicine, 26(1), 81-94. 